Joyful Learning Journal

\title{
PENGEMBANGAN MEDIA PEMBELAJARAN PREZI BERBASIS MIND MAPPING (PREPPING) PADA MUATAN PPKN
}

\section{Sukma Ratna Pratiwi , Florentina Widihastrini}

Jurusan Pendidikan Guru Sekolah Dasar, Fakultas Ilmu Pendidikan, Universitas Negeri Semarang, Indonesia

\begin{tabular}{l}
\hline Info Artikel \\
\hline Sejarah Artikel: \\
Diterima Januari \\
$\mathbf{2 0 2 0}$ \\
Disetujui Februari \\
$\mathbf{2 0 2 0}$ \\
Dipublikasikan \\
Maret 2020 \\
\hline Keywords: \\
Civics, mind mapping, \\
Prepping Learning \\
Media, Prezi \\
\hline
\end{tabular}

\begin{abstract}
Abstrak
Tujuan penelitian ini adalah untuk mengembangkan, menguji kelayakan, dan menguji keefektifan media pembelajaran Prezi berbasis mind mapping (Prepping) pada muatan PPKn kelas IV SD Negeri Pundenrejo Pati. Berdasarkan data prapenelitian melalui observasi, wawancara, dan dokumentasi di SDN Pundenrejo ditemukan permasalahan berupa media pembelajaran yang digunakan guru hanya terbatas pada gambar dan peta yang tertempel di dinding kelas serta belum memfasilitasi pembelajaran PPKn yang membutuhkan media berbasis teknologi sehingga menyebabkan motivasi dan hasil belajar siswa kurang optimal. Jenis penelitian ini adalah Research and Development $(R \& D)$ dengan model pengembangan Borg \& Gall yang diadaptasi oleh Sugiyono yang menggunakan 8 langkah yaitu: (1) potensi dan masalah; (2) pengumpulan data; (3) desain produk; 4) validasi desain; (5) revisi desain; (6) uji coba produk; (7) revisi produk; dan (8) uji coba pemakaian. Hasil penelitian menunjukan bahwa media pembelajaran Prepping sangat layak digunakan dengan presentase kelayakan penyajian oleh ahli media sebesar 90,63\%, kelayakan isi oleh ahli materi sebesar 93,75\% dan kelayakan kebahasaan oleh ahli bahasa sebesar $89,06 \%$. Hasil uji t yaitu thitung $=19,7061>$ tabel $=2,0553$, sehingga dapat disimpulkan bahwa pengembangan media pembelajaran Prepping efektif digunakan pada pembelajaran PPKn terhadap hasil belajar siswa. Hal ini diperkuat oleh $\mathrm{N}$-gain data pretest dan posttest sebesar 0,3821 dengan kriteria sedang.
\end{abstract}

\begin{abstract}
The purpose of this study was to develop, test the feasibility, and test the effectiveness of Prezi learning media based on mind mapping (Prepping) on civics in the fourth grade students of Pundenrejo Elementary School Pati. Based on the preresearch data through observation, interview, and documentation at Pundenrejo Elementary School, problems were found in the form of instructional media used by teachers just limited on pictures and maps attached to the classroom walls and had not covered the needs of civics learning which required technology-based media, so that caused the lack of students' motivation and learning outcomes. The type of study was Research and Development $(R \& D)$ with Borg \& Gall development model adapted by Sugiyono using 8 steps: (1) potential and problems; (2) data collection; (3) product design; 4) design validation; (5) design revisions; (6) product trials; (7) product revisions; and (8) trial use. The results showed that the Prepping learning media was very feasible to be used with the feasibility percentage by the media expert of $90.63 \%$, the content expert of $93.75 \%$, and the linguistic expert of $89.06 \%$. The $T$ test results showed $t_{\text {count }}=19.7061>t_{\text {table }}=2.0553$, so it could be concluded that the development of the Prepping learning media was effectively used to increase students' civics learning outcomes. This was reinforced by the $N$-gain of pretest and posttest data of 0.3821 with moderate criteria.
\end{abstract}

(C) 2020 Universitas Negeri Semarang

\footnotetext{
Alamat korespondensi:

Bulungan RT 05 RW 01, Tayu, Pati, Jawa Tengah, 59155

E-mail: sukmaratnapratiwi@gmail.com
}

ISSN 2252-6366 


\section{PENDAHULUAN}

PPKn merupakan usaha sadar untuk menyiapkan peserta didik menjadi patriot yang cinta, setia, serta berani membela tanah air melalui bidang profesinya masing-masing (Amin, 2018). Mata pelajaran ini digunakan sebagai sarana pengembangan dan pelestarian nilai luhur dan moral yang berakar pada budaya bangsa Indonesia (Susanto, 2015). Namun dalam aplikasinya PPKn kurang diminati karena materinya hanya dikemas dalam bentuk konsep dan hafalan serta belum dikembangkannya inovasi dalam pembelajaran. Hal ini sejalan dengan penelitian oleh Nusarastriya (2015) yang mengungkapkan bahwa PPKn dalam kenyataannya sering dipandang sebelah mata serta terkesan kurang menarik dan membosankan karena kurangnya inovasi media, materi, dan metode mengajar. Hal ini harus disikapi pendidik dan dijadikan tantangan dengan mengembangkan PPKn dari berbagai segi baik menyangkut media pembelajaran, materi, metode, serta proses pembelajarannya.

Berdasarkan kegiatan prapenelitian yang dilakukan oleh peneliti melalui observasi, wawancara, dan dokumentasi di SDN Pundenrejo ditemukan masalah terkait media pembelajaran yaitu penggunaan media pembelajaran yang belum menarik motivasi siswa untuk mengikuti pembelajaran PPKn. Media yang digunakan guru hanya terbatas pada gambar dan peta yang tertempel di dinding kelas serta belum memfasilitasi pembelajaran PPKn yang membutuhkan media berbasis teknologi, sehingga menyebabkan motivasi dan hasil belajar siswa kurang optimal.

Permasalahan tersebut didukung dengan data hasil belajar UAS siswa kelas IV semester 1 tahun pelajaran 2018/2019 di SDN Pundenrejo pada muatan PPKn yang menunjukkan banyaknya siswa yang belum mencapai KKM. Dari total 18 siswa, sebanyak 11 siswa (61\%) diantaranya belum mencapai KKM dan 7 siswa lainnya (39\%) sudah mencapai KKM, untuk KKM 70. Berdasarkan permasalahan tersebut, peneliti mengembangkan media pembelajaran Prezi berbasis mind mapping (Prepping) pada muatan PPKn kelas IV di SD Negeri Pundenrejo untuk membantu proses pembelajaran pengembangan media pembelajaran propping diharapkan dapat memudahkan siswa dalam belajar karena media dikemas dengan menarik dan inovatif melalui aplikasi Prezi dan dipadukan dengan mind map yang dapat membantu siswa untuk mengingat materi pembelajaran yang luas menjadi lebih mudah dipahami oleh siswa.

Rusyfian (2016) menjelaskan, Prezi adalah sebuah perangkat lunak yang digunakan untuk membuat presentasi yang dapat mengeksplorasi dan berbagi ide di atas kanvas virtual menggunakan metode Zooming User
Interface(ZUI),sehingga memungkinkan pengguna untuk memperbesar dan memperkecil tampilan media presentasi mereka secara bebas. Teks, gambar, video, dan media presentasi lainnya dapat ditempatkan di atas kanvas presentasi serta dapat dikelompokkan ke dalam bingkai yang telah disediakan oleh Prezi (Sari dan Fauzi, 2018). Media ini dapat digunakan sebagai alat untuk membuat presentasi dalam bentuk linear seperti presentasi terstruktur, maupun presentasi non-linear seperti presentasi yang berbentuk peta-pikiran (mind map) (Rohiman dan Anggoro, 2019). Whicker \& Tucker (2015) menambahkan bahwa Prezi juga menyediakan berbagai template dan grafik yang berguna untuk menciptakan hubungan visual dan peta konsep serta memberikan kebebasan untuk menyusun presentasi dari goresan-goresan kecil. Penggunaan Prezi dan mind map akan membantu meningkatkan efektivitas penyajian informasi karena didukung oleh fitur-fitur luar biasa dari Prezi (Diamond, 2010).

Buzan (2012) menyatakan bahwa mind map adalah cara mencatat yang kreatif, efektif, dan sederhana yang memungkinkan seseorang menyusun fakta dan pikiran dengan melibatkan cara kerja alami otak sehingga informasi akan lebih mudah diingat. Sejalan dengan hal tersebut Swadarma (2013) menyatakan mind mapping adalah teknik pemanfaatan keseluruhan otak dengan menggunakan citra visual dan prasarana grafis lainnya untuk membentuk kesan. Hal ini dapat membangkitkan ide-ide orisinil dan memicu ingatan yang mudah dengan mengaktifkan kedua belahan otak secara menenangkan, menyenangkan, dan kreatif (Shoimin, 2014). Huda (2014) menjelaskan bahwa mind map dikembangkan sebagai metode efektif untuk mengembangkan gagasan-gagasan melalui petapeta. Arbai dkk (2014) juga menyatakan bahwa seseorang dapat mengingat banyak informasi dan akan disimpan lebih lama dalam memori karena mind mapping memanfaatkan kerja otak kanan dan otak kiri. Keseimbangan antara kedua belahan otak akan membuat otak "senang" sehingga muncul ketertarikan dan emosi yang positif untuk belajar lebih dalam lagi (Munandar, 2016).

Penelitian yang mendukung penelitian ini adalah penelitian dengan judul Penggunaan Media Presentasi Berbasis Software Prezi Untuk Meningkatkan Hasil Belajar Siswa Pada Mata Pelajaran IPS Kelas V SDN Warugunung 1 Karangpilang Surabaya oleh Putra (2018). Hasilnya adalah penggunaan media presentasi Prezi dapat meningkatkan hasil belajar siswa pada mata pelajaran IPS kelas V SDN Warugunung 1 Karangpilang Surabaya. Hal ini dilihat dari presentase ketuntasan belajar siswa setelah mengikuti evaluasi yang mengalami peningkatan dari $62,8 \%$ menjadi $85,7 \%$. Selain itu pengembangan media berbasis mind mapping juga didukung oleh penelitian yang dilakukan 
oleh Masita dan Wulandari (2018) dengan judul Pengembangan Buku Saku berbasis Mind Mapping pada Pembelajaran IPA. Hasil penelitiannya yaitu skor rata-rata kevalidan media sebesar $88 \%$ dengan kategori sangat valid. Selain itu, hasil uji t menunjukkan adanya perbedaan hasil belajar siswa yang menjadi lebih baik setelah melakukan pembelajaran menggunakan buku saku berbasis mind mapping dan didukung dengan hasil uji $\mathrm{n}$-gain sebesar 0,64 yang termasuk kategori sedang. Hal ini menunjukan bahwa media tersebut layak dan efektif digunakan dalam pembelajaran.

Rumusan masalah dalam penelitian ini adalah: (1) bagaimanakah desain pengembangan media pembelajaran Prezi berbasis mind mapping (Prepping) pada muatan PPKn kelas IV SD Negeri Pundenrejo Pati?; (2) bagaimanakah kelayakan media pembelajaran Prezi berbasis mind mapping (Prepping) pada muatan PPKn kelas IV SD Negeri Pundenrejo Pati?; dan (3) bagaimanakah keefektifan media pembelajaran Prezi berbasis mind mapping (Prepping) pada muatan PPKn kelas IV SD Negeri Pundenrejo Pati?

Berdasarkan rumusan masalah tersebut, tujuan penelitian ini adalah: (1) mengembangkan media pembelajaran Prezi berbasis mind mapping (Prepping) pada muatan PPKn kelas IV SD Negeri Pundenrejo Pati; (2) menguji kelayakan media pembelajaran Prezi berbasis mind mapping (Prepping) pada muatan PPKn kelas IV SD Negeri Pundenrejo Pati; dan (3) menguji keefektifan media pembelajaran Prezi berbasis mind mapping (Prepping) pada muatan PPKn kelas IV SD Negeri Pundenrejo Pati.

\section{METODE PENELITIAN}

Jenis penelitian yang digunakan dalam penelitian ini adalah penelitian pengembangan dengan menggunakan model pengembangan Borg \& Gall yang diadaptasi oleh Sugiyono dengan 8 langkah yaitu: (1) potensi dan masalah; (2) pengumpulan data; (3) desain produk; (4) validasi desain; (5) revisi desain; (6) uji coba produk; (7) revisi produk; dan (8) uji coba pemakaian.

Variabel penelitian berupa media pembelajaran Prepping dan hasil belajar PPKn materi keragaman suku bangsa, bahasa daerah, dan agama di Indonesia yang terikat persatuan dan kesatuan yang ditekankan pada aspek kognitif. Populasi dalam penelitian ini meliputi seluruh siswa kelas IV SDN Pundenrejo Pati tahun ajaran 2019/2020 sejumlah 28 siswa. Pengambilan sampel pada penelitian uji coba produk dilakukan melalui teknik sampling purposive, yaitu teknik penentuan sampel dengan pertimbangan tertentu(Sugiyono,2015).

Pertimbangan dalam mengambil sampel ini dilakukan berdasarkan peringkat kelas, yaitu 2 siswa peringkat atas, 2 siswa peringkat tengah, dan 2 siswa peringkat bawah sehingga diperoleh sampel sebanyak 6 siswa yang heterogen. Teknik pengumpulan data menggunakan teknik tes dan non tes. Teknik tes berupa pretest dan posttest yang digunakan untuk mengetahui keefektifan media pembelajaran Prepping pada muatan PPKn kelas IV SD Negeri Pundenrejo Pati. Teknik non tes menggunakan insrumen berupa angket kebutuhan guru dan siswa, angket penilaian ahli, angket tanggapan guru dan siswa, dan dokumentasi.

Teknik analisis data menggunakan analisis data produk berupa analisis kelayakan media serta analisis tanggapan guru dan siswa, analisis data awal berupa uji normalitas, dan analisis data akhir berupa analisis data uji t dan $N$-gain. Analisis data produk digunakan untuk mengetahui kelayakan media pembelajaran Prepping pada muatan PPKn kelas IV. Analisis data awal digunakan untuk menentukan statistic yang akan digunakan untuk mengolah data dengan menguji hasil belajar pretest dan posttest. Analisis data akhir berupa uji $t$ digunakan untuk mengetahui perbedaan rata-rata hasil belajar PPKn sebelum dan sesudah menggunakan media pembelajaran Prepping, sedangkan uji N-gain untuk mengetahui peningkatan rata-rata hasil belajar.

\section{HASIL DAN PEMBAHASAN}

Hasil penelitian dan pengembangan media pembelajaran Prezi berbasis mind mapping (Propping) pada muatan PPKn kelas IV materi keragaman suku bangsa, bahasa daerah, dan agama di Indonesia yang terikat persatuan dan kesatuan meliputi: (1) hasil pengembangan media pembelajaran Prezi berbasis mind mapping (Prepping) pada muatan PPKn Kelas IV; (2) kelayakan media pembelajaran Prezi berbasis mind mapping (Prepping) pada muatan PPKn Kelas IV oleh validator ahli; dan (3) keefektifan media pembelajaran Prezi berbasis mind mapping (Prepping) pada muatan PPKn Kelas IV.

\section{Hasil Pengembangan Media Pembelajaran Prezi Berbasis Mind Mapping (Prepping) pada Muatan PPKn}

Media pembelajaran Prepping merupakan media pembelajaran berbentuk presentasi Prezi dengan materi yang disusun menggunakan konsep mind mapping sehingga memiliki tampilan yang menarik dan menumbuhkan semangat belajar siswa. Media pembelajaran Prepping didesain menggunakan aplikasi Prezi dengan beberapa aplikasi pendukung seperti cracklock 3.9.44, CorelDRAW X7, Microsoft Word, dan PDF. Hasil akhir produk memiliki format exe dalam bentuk portable prezi (semacam versi download Prezi yang bisa digunakan secara offline namun tidak bisa diedit) sehingga dapat dibuka pada perangkat yang tidak terinstal Prezi. 
Validasi Kelayakan Media Pembelajaran Prezi Berbasis Mind Mapping (Prepping) pada Muatan PPKn

Media pembelajaran Prezi berbasis mind mapping (Prepping) pada muatan PPKn divalidasi kelayakannya oleh validator ahli media, ahli materi, dan ahli bahasa. Penilaian kelayakan penyajian media oleh ahli media dilakukan dengan satu kali perbaikan, penilaian kelayakan isi oleh ahli materi dilakukan dengan dua kali perbaikan, dan penilaian kelayakan kebahasaan oleh ahli bahasa dilakukan dengan satu kali perbaikan. Berikut tabel rekapitulasi hasil validasi kelayakan media Prepping.

Tabel 1 Rekapitulasi Hasil Validasi Penilaian Kelayakan Media

\begin{tabular}{|c|c|c|c|}
\hline $\begin{array}{c}\text { Validator/ } \\
\text { Ahli } \\
\end{array}$ & $\begin{array}{c}\text { Jumlah } \\
\text { Skor } \\
\end{array}$ & Presentase & Kriteria \\
\hline Media & 58 & $90,63 \%$ & $\begin{array}{c}\text { Sangat } \\
\text { layak }\end{array}$ \\
\hline Materi & 60 & $93,75 \%$ & $\begin{array}{c}\text { Sangat } \\
\text { layak }\end{array}$ \\
\hline Bahasa & 57 & $89,06 \%$ & $\begin{array}{c}\text { Sangat } \\
\text { Layak }\end{array}$ \\
\hline
\end{tabular}

Berdasarkan Tabel 1 diketahui bahwa media Prepping memperoleh skor 58 dengan presentase $90,63 \%$ yang termasuk kriteria sangat layak dari ahli media, skor 60 dengan presentase $93,75 \%$ yang termasuk kriteria sangat layak dari ahli materi, dan skor 57 dengan presentase 89,06\% yang termasuk kriteria sangat layak dari ahli bahasa. Hasil tersebut menunjukkan bahwa media pembelajaran Prepping telah memenuhi kelayakan penyajian, kelayakan isi, dan kelayakan kebahasaan sehingga layak digunakan dalam pembelajaran muatan PPKn materi keragaman suku bangsa, bahasa daerah, dan agama di Indonesia yang terikat persatuan dan kesatuan kelas IV.

Aspek kajian empiris yang mendukung penelitian ini adalah penelitian yang dilakukan oleh Istiawan dkk (2016). Berdasarkan uji kelayakan pada pengembangan media prezi mind map materi alat optik diperoleh hasil persentase kelayakan sebesar 4,2 dengan kriteria sangat layak. Penggunaan media pembelajaran ini juga dapat meningkatkan pemahaman konsep siswa sebesar 0,416 dengan kategori peningkatan sedang.

Penelitian internasional yang mendukung dilakukan oleh Hartini dkk (2017). Hasil penelitian menunjukkan bahwa media Prezi tersebut layak untuk digunakan karena termasuk ke dalam kategori media yang sangat valid dengan rata-rata skor 3,25 , termasuk kategori sangat praktis berdasarkan angket tanggapan dengan rata-rata 3,50, dan termasuk kategori efektif dengan N-Gain 0,70 sehingga diperoleh kesimpulan bahwa Prezi memenuhi syarat untuk digunakan dalam proses pembelajaran.
Penelitian internasional lain yang mendukung penelitian ini yaitu dilakukan oleh Sari \& Sakdiah (2016). Hasil penelitian menunjukkan hasil bahwa media mind mapping layak untuk digunakan dan dapat memfasilitasi siswa dalam mempelajari materi. Hal ini dapat dilihat dari hasil penilaian dua validator ahli sebesar $94,11 \%$ dan $89,7 \%$ yang menunjukkan bahwa media mind mapping termasuk kategori sangat layak.

\section{Keefektifan Media Pembelajaran Prezi Berbasis Mind Mapping (Prepping) pada Muatan PPKn}

Keefektifan media pembelajaran Prepping dapat diketahui melalui hasil belajar siswa yaitu nilai pretest dan posttest. Peneliti menggunakan teknik statistika parametik dengan rumus $t$-test berpasangan (paired sample t-test) dengan bantuan Ms. Excel untuk mengetahui perbedaan rata-rata hasil belajar sebelum dan sesudah menggunakan media pembelajaran

Prepping. Jika $t_{\text {hitung }}>\mathrm{t}_{\text {tabel }}$ maka Ha diterima dan sebaliknya. Berikut adalah tabel hasil perhitungan uji perbedaan rata-rata pretest dan posttest.

Tabel 2 Uji Perbedaan Rata-Rata Pretest dan Posttest

\begin{tabular}{cccc}
\hline $\begin{array}{c}\text { Jumlah } \\
\text { siswa }\end{array}$ & $\begin{array}{c}\text { Rata-rata } \\
\text { posttest-pretest }\end{array}$ & & \\
& & thitung & tabel \\
\hline 28 & 14,46 & 19,7061 & 2,0553 \\
\hline
\end{tabular}

Berdasarkan Tabel 2 diketahui hasil $t_{\text {hitung }}$ lebih besar dari $t_{\text {tabel }}(19,7061>2,0553)$ sehingga Ha diterima, dan Ho ditolak. Hal ini berarti terdapat perbedaan yang signifikan antara hasil belajar sebelum dan sesudah menggunakan media pembelajaran Prepping sehingga dapat disimpulkan bahwa pengembangan media pembelajaran Prepping efektif digunakan pada pembelajaran PPKn terhadap hasil belajar siswa.

\section{Hasil Peningkatan Rata-Rata (N-Gain)}

Uji $N$-gain dilakukan dalam penelitian ini untuk mengetahui rata-rata peningkatan nilai pretest dan posttest. Hasil peningkatan rata-rata data pretest dan posttest dapat dilihat pada tabel berikut.

Tabel 3 Hasil Uji Rata-Rata ( $N$-gain)

\begin{tabular}{cc}
\hline Kategori & Nilai \\
\hline Pretest & 62,14 \\
Posttest & 76,61 \\
Selisih rata-rata & 14,4643 \\
N-gain kelas & 0,3821 \\
Kriteria & Sedang \\
\hline
\end{tabular}

Berdasarkan Tabel 3 diketahui bahwa hasil belajar siswa kelas IV SDN Pundenrejo mengalami peningkatan rata-rata dengan kriteria 
sedang sebesar 0,3821 dan selisih rata-rata sebesar 14,4643 .

Penelitian yang mendukung keefektifan penggunaan media pembelajaran Prezi dilakukan oleh Antika dan Suprianto (2016). Berdasarkan penelitian tersebut diketahui bahwa uji peningkatan (gain) yang diawali dengan mengubah nilai pretest dan posttest menjadi nilai gain memperoleh peningkatan rata-rata gain hasil belajar siswa sebesar 0.79 dan termasuk kriteria tinggi. Hal ini menunjukkan bahwa penggunaan media pembelajaran berbasis Prezi pada mata pelajaran Rangkaian Elektronika efektif digunakan karena terdapat peningkatan rata-rata nilai pretest dan posttest.

Pada penelitian internasional yang dilakukan oleh Akgun dkk (2016) juga mendukung bahwa penggunaan media pembelajaran Prezi dapat meningkatkan proses kognitif siswa. Hasil penelitian tersebut menunjukkan bahwa siswa yang diajar menggunakan presentasi Prezi memiliki kemampuan belajar konsep yang meningkat dan proses kognitif dan lebih cepat pada materi sistem jaringan komputer. Jadi Prezi adalah alternatif yang tepat untuk pembelajaran konsep.

Sementara itu penelitian yang mendukung keefektifan mind mapping terhadap hasil belajar dilakukan oleh Masita dan Wulandari (2018) yang dapat diketahui dari hasil uji $\mathrm{t}$ dan diperkuat dengan uji peningkatan rata-rata (gain) nilai pretest dan posttest siswa. Berdasarkan uji t diperoleh hasil Ho ditolak karena $\mathrm{t}$ hitung $>\mathrm{t}$ tabel $(20,4771>$ $2,0930)$. Hal ini berarti terdapat perbedaan hasil belajar siswa yang menjadi lebih baik setelah melakukan pembelajaran menggunakan buku saku berbasis mind mapping. Selain itu terdapat gain sebesar 0,64 dengan kategori sedang dan selisih rata-rata hasil belajarnya sebesar 32 . Jumlah siswa yang tuntas pada pretest dan posttest juga mengalami peningkatan dari 6 siswa $(30 \%)$ menjadi 20 siswa (100\%). Maka dapat disimpulkan buku saku berbasis mind mapping pada pembelajaran IPA materi kalor dan perpindahannya efektif digunakan dalam pembelajaran.

Selain itu, pada penelitian internasional yang dilakukan oleh Wibowo (2017) juga mendukung penggunaan model pembelajaran mind mapping yang dapat meningkatkan hasil belajar siswa. Hasil penelitian menunjukkan bahwa penerapan model pembelajaran mind mapping dapat meningkatkan prestasi belajar IPA siswa kelas V SD. Hal ini dapat dilihat dari adanya peningkatan ketuntasan belajar siswa dari 65,7 menjadi $82,34 \%$ pada pembelajaran IPA.

\section{SIMPULAN}

Media pembelajaran Prezi berbasis mind mapping (Prepping) pada muatan PPKn kelas IV dikembangkan menggunakan metode pengembangan Research and Development (R\&D) dengan model pengembangan Borg \& Gall yang diadaptasi oleh Sugiyono. Media pembelajaran Prepping telah memenuhi penilaian kelayakan dari tiga ahli (validator) dengan kategori sangat layak, yakni memperoleh presentase $90,63 \%$ untuk kelayakan penyajian media dari ahli media, presentase $93,75 \%$ untuk kelayakan isi dari ahli materi, dan presentase $89,06 \%$ untuk kelayakan kebahasaan dari ahli bahasa. Penggunaan media pembelajaran Prepping efektif digunakan dalam pembelajaran PPKn terhadap hasil belajar siswa. Hal ini ditunjukkan oleh uji perbedaan rata-rata ( $t$ test) yang memperoleh hasil thitung lebih besar dari $t_{\text {tabel }}(19,7061>2,0553)$ sehingga Ha diterima, dan Ho ditolak.

Hal ini berarti terdapat perbedaan yang signifikan antara hasil belajar sebelum dan sesudah menggunakan media pembelajaran Prepping. Selain itu terdapat peningkatan rata-rata ( $N$-Gain) sebesar 0,3821 yang termasuk kriteria sedang.

\section{UCAPAN TERIMA KASIH}

Peneliti mengucapkan terima kasih kepada orangtua atas dukungan dan doa yang diberikan, dosen pembimbing Dra. Florentina Widihastrini, M.Pd. serta mitra bestari yang telah memberikan bimbingan, masukan, dan arahan dalam menyusun manuskrip ini.

\section{DAFTAR PUSTAKA}

Akgun. 2016. Effects of lectures with powerpoint or prezi presentations on cognitive load, recall, and conceptual learning. International Online Journal of Educational Sciences, 2016, 8 (3), 1-11. ISSN: 1309-2707.

Amin, Z. I. 2018. Pendidikan kewarganegaraan. Tangerang Selatan: Universitas Terbuka.

Antika, Y. \& Siprianto, B. 2018. Pengembangan media pembelajaran berbasis prezi sebagai upaya meningkatkan hasil belajar siswa kompetensi dasar aplikasi rangkaian opamp mata pelajaran rangkaian elektronika di SMK Negeri 2 Bojonegoro. Jurnal Universitas Negeri Surabaya. Volume 05 Nomor 02 Tahun 2016, 493 - 497.

Arbai, S. Y. dkk. 2014. Pengembangan modul IPA terpadu bermuatan mind mapping pada tema cahaya dan penglihatan untuk kelas VIII SMP/MTs. Unnes Science Education Journal 3 (1) (2014). ISSN 22526609

Buzan, T. 2012. Buku pintar mind map. Jakarta: PT Gramedia Pustaka Utama. 
Diamond, S. 2010. Prezi for dummies. Canada: Wiley Publishing, Inc., Indianapolis, Indiana.

Hartini, Misbah, Dewantara, Oktovian, dan Aisyah. 2017. Developing learning media using online prezi into materials about optical equipments. JPII 6 (2) (2017) 313317

Huda,2014. Model-model pengajaran pembelajaran. Yogyakarta: Pustaka Pelajar

Istiawan, R. 2016. Pengembangan media prezi mind map untuk meningkatkan pemahaman konsep fisika materi alat optik pada siswa SMA kelas X peminatan IPS. Unnes Physics Education Journal (UPEJ). 5 (3) (2016) hal 87-93.

Masita, M. \& Wulandari, D. 2018. Pengembangan buku saku berbasis mind mapping pada pembelajaran IPA. Jurnal Kreatif, 8(2):191-198.

Munandar, W. A. 2016. Media mind map untuk meningkatkan retensi siswa dalam pembelajaran pendidikan kewarganegaraan kelas III. Jurnal Pendidikan Guru Sekolah Dasar Edisi 18 Tahun ke-5 2016

Nusarastriya, Y. H. 2015. Permasalahan dan tantangan guru PKn menghadapi perubahan kurikulum (2013). Vol. 29, No.1. Juni 2013: 23-29

Rohiman \& Anggoro, B. S. 2019. Penggunaan prezi untuk media pembelajaran matematika materi fungsi. Jurnal Matematika. Vol 2 (1), 2019, 23-32. Print ISSN: 2613-9073, Online ISSN: 2613-9081 Rusyfian, Z. 2016. Prezi solusi presentasi masa kini. Bandung: Informatika

Sari, E. R. N. \& Fauzi, R. U. A. 2018. Analisis penerapan media prezi terhadap hasil belajar pada mata kuliah Bahasa Inggris. Seminar Nasional Hasil Penelitian dan Pengabdian kepada Masyarakat UNIPMA

Sari, A. S. \& Sakdiah, H. 2016. The development of mind mapping media in flood material using ADDIE model. Journal of Education and Learning. Vol. 10 (1) pp. 53-62

Shoimin, A. 2014. 68 Model pembelajaran inovatif dalam kurikulum 2013. Yogyakarya: ArRuzz Media

Subiantoro, D. 2016. Penerapan model pembelajaran mind mapping dengan media prezi terhadap hasil belajar siswa pada mata pelajaran Konstruksi Bangunan kelas $\mathrm{X}$ Teknik Bangunan SMKN 1 Sidoarjo. Jurnal Kajian Pendidikan Teknik Bangunan, Vol 2 Nomer 2/JKPTB/16 (2016) : 200 205.

Sugiyono. 2015. Metode penelitian pendidikan. Bandung: Alfabeta

Susanto. 2015. Teori belajar dan pembelajaran di sekolah dasar. Jakarta: Kencana Prenadamedia Group

Whicker, J. R. \& Tucker, K R. 2016. Using prezi to structure online videos for information literacy instruction: a case study. Internet Reference Services Quarterly, 20:89-96, 2015 ISSN: 1087-5301 print / 1540-4749 online.

Wibowo, N. 2017. An application of mind mapping teaching model model to enhance natural science learning achievement in the fifth graders in the first semester at SD N 4 Kaliuntu. International Journal of Elementary Education. Vol.1 (4) pp. 250254. 